\title{
EVOLUTIONARY MODEL FAMILY BUSINESS - concept of special model
}

\author{
Zdeněk Mikolášs, ${ }^{1, *}$, Iveta Vozňáková ${ }^{2}$ \\ ${ }^{1}$ VŠPP Praha, Spálená 76/14, 11000 Praha - Nové Město, Czech Republic \\ ${ }^{2}$ VŠPP Praha, Spálená 76/14, 11000 Praha - Nové Město, Czech Republic
}

\begin{abstract}
The authors of the article present the practical and theoretical knowledge which they have achieved in the framework of the entrepreneurship research over the past 10 years. The practical and research activities have focused in the last period, in particular, on the synergy of the links between the family business, innovative dynamism and competitiveness of the companies. The paper offers a generalization of the findings to the theory of synergy, economics of the time, the family business, especially in the innovation and dynamism of the evolutionary family business potential in the process of succession. The findings are also based on empirical research in more than 230 small and medium-sized family companies in the Czech Republic and Poland. Presented results deserves a broad discussion and verification in practice, depending on the cultural differences in manifestations of globalization in various parts of the world and under the influence of the industrial revolution 4:0
\end{abstract}

\section{Teoretical background}

The practical and research activities have focused in the last period (over the past 10 years), in particular, on the synergy of the links between the family business, innovative dynamism and competitiveness of the companies. The paper offers a generalization of the findings to the theory of the family business, especially in the dynamism of the evolutionary family business potential in the process of succession. The findings are also based on empirical research in more than 230 small and medium-sized family companies in the Czech Republic and Poland. Presented results deserves a broad discussion and verification in practice, depending on the cultural differences in manifestations of globalization in various parts of the world and under the influence of the industrial revolution 4:0. The following text is based on the theoretical conclusions of previous research projects $[4,5,6,7,8,9,10,11,12,13]$.

\footnotetext{
*Corresponding author: zdenek.mikolas@,vspp.cz, iveta.voznakova@vspp.cz
} 


\subsection{Key terms of the problem}

Family business defines the synergies (unification) with 4 subsystems (circles) $[5,7,8,11,12]$ : family, business (family business), environment and outputs.

Entrepreneurship is a process of the formation of something else, which belongs to a value, by spending the necessary time and effort, taking accompanying financial, psychological and social risks, and the acquisition of the resulting rewards in a form of funds and personal satisfaction .

Family is, in the sociology, a solidarity group of persons related to each other by marriage, relationships or adoption, that they live together in the long term and whose adult members are responsible for the upbringing of children.

Potential is the difference between what it is and what it can be (results from knowledge) or it must be (results from natural and legal laws).

\subsection{The concept of evolutionary business modeling}

The concept of evolutionary business modeling is based on business diagnostics and therapeutics, on a specific approach of scientific research known as "empiriology", based on experience, comparing knowledge with available theoretical knowledge, then formulating new theories and validating them empirically (experiments) in practice.

The author of the model (Z. Mikoláš) combines the Sarasvathy [15] effectuation and causal logic. Together, these principles lead to an effective way of reasoning and acting, drawing on the potential of previous generations.

\section{Evolutionary model family business}

\subsection{The morphology of the potentials}

The total potential of the family business has this basic morphology of $\mathrm{P}=\mathrm{A}+\mathrm{B}+\mathrm{C}$, where $\mathrm{A}$ is the effective potential (changed with the effect/E outputs), $\mathrm{B}$ is the spending potential (changed with the amount of spent resources $M$ to achieve effects $E$, it also has the potential to eliminate the negative emissions and losses), and $\mathrm{C}$ is the stabilized potential (deferred for the next generation), in greater details $[8,9,10,11,12,13]$.

\subsection{Spontaneous order of network synergy potentials}

The above mentioned morphology of the potential for the family business is dynamically changing by the spontaneous order of objective and subjective factors. It manifests itself in the form of a combination synergy of objective and subjective order effects and spontaneity in the form of threats, opportunities, strengths and weaknesses of the family business.

The following text contains generalized research findings of the authors that describe the "ideal theoretical" variant of a family business that is carried out in the framework of the objective of "natural" order and the rational subjective (human) behaviour (negentropy) by accepting the objective and the subjective spontaneity (entropy) $[8,9,10,11,12,13]$.

\subsection{Evolutionary dynamism}


The ideal theoretical variant of the family business relies on the validity of the two basic natural and social evolutionary principles (it follows: laws of nature, instincts, reflexes):

$P_{i+1}>P_{i}$ a $\left(A_{i+1}+B_{i+1}\right)>\left(A_{1}+B_{1}\right)$ two consecutive generations $(i, i+1)$ of family business.

Therefore, under such conditions of the basic evolutionary (reproductive) legality for the two consecutive generations of the productive system, it is possible to write down in the following two variants:

a) $\chi_{i+1}=P_{i+1}: P_{i}>2-\left(C_{i}: P_{i}\right)$,

b) $\chi_{i+1}=1+\left(\left(A_{i}+B_{i}\right): P_{i}\right)$.

Family business is characterized by these two propensities:

a) propensity to consumption $1<\alpha_{i}=\left(P_{i}-C_{i}\right): P_{i}>0$,

b) propensity to save $\beta_{i}=1:\left(\left(P_{i}-C_{i}\right): C_{i}\right)>0$. Be notified of "a new fuzzy" philosophy of the concept of reproduction (evolution), which offers not only standard an analytical view, so-called, what proportion has the part in whole -see a) equation propensity to consumption, but it also searches for the answer to the question what is the future of all $(i+1)$ in the old part (i), from which it draws its foundation - see b) the equation of propensity to save. Propensity for consumption and savings are indirectly commensurate with the relationship.

It follows derivation of the formulas is indicated in sources the perfect growth potential (P) of family business the two consecutive generations $(i, i+1)$ is equal to the number $\varphi=$ $\mathrm{P}_{\mathrm{i}+1}: \mathrm{P}_{\mathrm{i}}$. This growth dynamism is given by the ratio of stabilized (for the next generation of delay) potential $(\mathrm{C})$ to the total potential $(\mathrm{P})$ of the previous generation (i), that is, $\varphi=2$ $-\left(\mathrm{C}_{\mathrm{i}}: \mathrm{P}_{\mathrm{i}}\right)$.

Finding the balance between the two propensities (for consumption and savings) we come to several optimal values:

a) $\gamma=C_{i}: P_{i}=2-\varphi$, approx. $\gamma=0,382$,

b) $\omega=\left(A_{i}+B_{i}\right): P_{i}=\varphi-1$, approx. $\omega=0,618$,

c) $\vartheta=C_{i}:\left(A_{i}+B_{i}\right)=\varphi-1$, approx. $\vartheta=0,618$.

Therefore, if the default (i) generation lays down approximately $38.2 \%$ of your potential for the future generation, then the following generation (i+1) will increase the total potential of approximately $61.8 \%$ compared to the total potential of the previous generation (i). Therefore, the total consumption $(\mathrm{A}+\mathrm{B})$ of default generation (i) is approximately $61.8 \%$ of the total potential $(\mathrm{P})$, but also the proportion of deferred (stabilized) potential (C) on consumption $(\mathrm{A}+\mathrm{B})$ is also around $61.8 \%$.

At the same time we can deduce that $\varphi=1+\sum_{i=1}^{n}\left(\mathbf{1}: \boldsymbol{\varphi}^{\mathrm{i}}\right)^{2}$, for $\mathbf{n}$ approaching asymptotically to $(+\infty)$.

In other words, the ideal dynamics of the growth potential of the family business is defined by a number of evolution potentials from (I) the present $\left(\mathrm{P}_{\mathrm{i}}=1\right)$ up to the past (asymptotically in the endless series of "ancestors", II, III, IV, ...). The referred argument we can graphically demonstrate. 


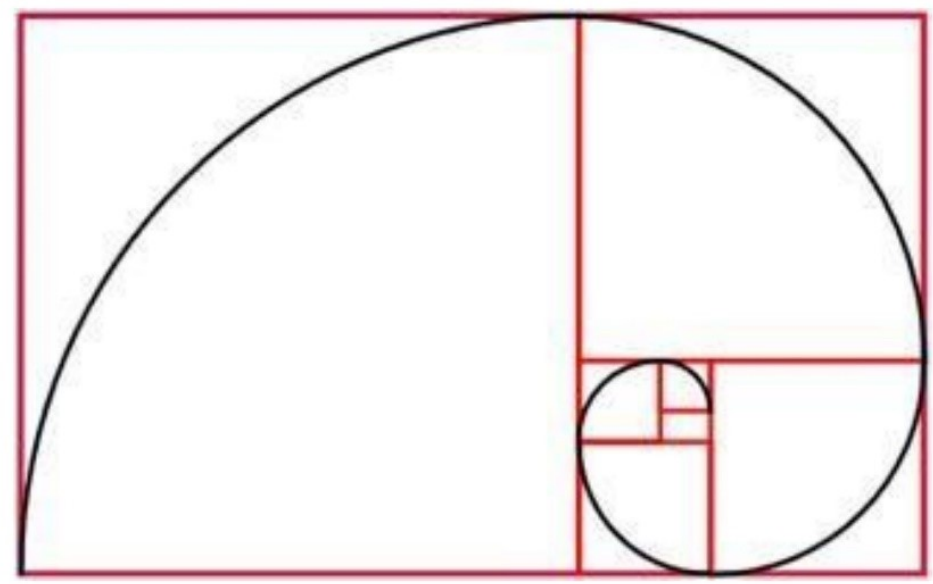

Fig. 1. Evolutionary series of potentials in business Source: authors

\subsection{Optimization proportions of the golden ratio}

Everything what is in nature composed so that the result was "appealing" harmony, is related to the golden ratio. Such objects and phenomena are not only more beautiful, but also healthier, effective and work better. This phenomenon has its deep causes that express themselves in many different areas of mathematics (such as the proportions of Platonic solids ), computer science (e.g. the theory of heaps) through biology (shapes of the shells, horns, the proportions of DNA), music, modern and ancient architecture to astronomy (such as parameters or conditions of the orbits) or physics, which won its specific name golden physics . It is obvious that even most of the proportions of nature are directed by the golden ratio, and if it does not control, it is not such harmonious proportions.

Due to the fact that economics is an optimization science, it should be reflected also in this area. The task of an economist is in collaboration with experts in the area to find the most effective solution to achieve the given objective with regards to thrifty treatment of rare resources. So we find that the phyllotaxis, i.e. the spiral-shaped layout of the leaves on the stem in the proportions of the golden ratio allows to make the best use of solar radiation. Optimum use of space represents so-called the golden tree, whose branches are becoming shorter in proportion of the golden ratio (e.g. lungs).

This article is mostly implicating the issue of optimizing the development of the family business. Development of economic (commerce) systems in different hierarchical levels is rarely uniform, but almost it always shows a tendency. Here you can view the features in the chart with the Cartesian coordinates, where the $\mathrm{x}$ axis is time, or in polar coordinates, where the time is represented by evenly increasing angle $(\alpha)$ and development is given by extending of radius vector (r). Development is then modelled by the spiral. If the radius vector grows in proportion to the angle (a parameter of proportionality is (a)) that is the Archimedes' spiral, which corresponds to a clear extensive development, i.e. the development without innovation achieved by simply expanding of a production range. Therefore, $r=a^{*} \alpha$.

Clear intense development, which is supported by the only innovation, is given by the logarithmic spiral and in a real life is virtually unattainable, therefore $r=a^{*} e^{b . \alpha}$. The so-called "Golden spiral" represents a harmonious development, which is sustainably innovative.

\subsection{The evolutionary law of economics time in family business}


For the total potential of family business $\mathrm{P}=\mathrm{A}+\mathrm{B}+\mathrm{C}$ results from economic theory (economics of time) relationship $\mathrm{A}=\mathrm{B}^{*} \mathrm{v}$. Where $\mathrm{A}$ is the effective potential (changing into effect $\mathrm{E}$ ), $\mathrm{B}$ is spending (changing into resources spent on mass $\mathrm{M}$ ), whereas $\mathrm{v}$ is the speed of productive transformation of the effective potential B upon the spending potential A. In economic theory and practice, these general characteristic is referred differently: labour productivity, profitability, yield, efficiency, etc.

Descriptive analysis (Figure 2) of behaviour in family companies we have come to the conclusion that the following two generation of family business innovate a productive transformation with increasing speed, i.e., $\mathrm{v}_{\mathrm{i}+1}>\mathrm{v}_{\mathrm{i}}$. Ideal acceleration can be described by circles $\mathrm{k}$ (circumscribed square ABCD) and 1 (inscribed in a square ABCD). Radius of circle $\mathrm{k}\left(\right.$ abscissa $\mathrm{u}$ ) is equal to the speed of the transformation of the new generation $v_{i+1}$. Radius of the inscribed circle 1 (abscissa $w$ ) is equal to the speed of the transformation of the previous generation $\mathrm{v}_{\mathrm{i}}$. The derivation of that relationship is done in resources $[11,12]$.

It follows that the optimal pace of accelerating with innovation cycles (dynamism of generations change) of productive transformation is when $v_{i+1}=v_{i} * \sqrt{ } 2$, or approximately $v_{i+1}$ $=\mathrm{V}_{\mathrm{i}} * 1,414$. At the same time that the optimal pace of contraction of relative time in innovation cycles ("business" time) of productive transformation is $t_{i+1}=1$ : $\left(t_{i} * \sqrt{ } 2_{i}\right)$ or approximately $\mathrm{t}_{\mathrm{i}+1}=\mathrm{t}_{\mathrm{i}} * 0,7071$.

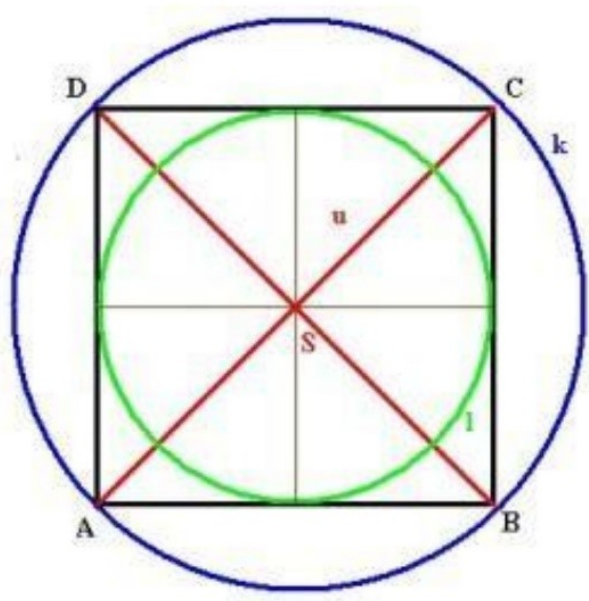

Fig. 2. Evolutionary series of productive transformation speed Source: authors

Summing up the above findings, then we can write an equation of $B_{i+1}=(\varphi-1):\left(v_{i+1}+1\right)$, when an ideal evolutionary growth is true relationship $B_{i+1}=(\varphi-1):\left(\left(v_{i} * \sqrt{2}\right)+1\right)$, for $i=0$, $1, \ldots, n(+\infty)$. Alternatively, we can write $v_{i+1}=v_{i} * \sqrt{2}$, for $i=0,1, \ldots, n(+\infty)$. Therefore, the speed in the following cycles in the ideal order increases in multiples of $\sqrt{2}$ and time of productive transformation (the existence of consecutive cycles) is shortened in multiples of $1: \sqrt{ } 2[11,12]$.

If the speed of transformation vi is the basic unit (scale) for changes in the family business for the next two generations, we can be regarded as the unit metrics $v i=1$, than $v_{i+1}$ $=\sqrt{ } 2$. Therefore, $\xi=v_{i+1}: v_{i}=\sqrt{2}$. And it can be used for the default (basic) generation of a productive system to infer the approximate ratio of $\delta_{i}=B_{i} / P_{i}=0,309$. And for the next generation of the productive system is: $\delta_{i+1}=B_{i+1} / P_{i+1}=0,256$. It follows that the proportion of the mass of resources on the overall potential is reduced, $\delta_{\mathrm{i}+1}<\delta_{\mathrm{i}}$.

The optimum ratio of the speed of the two following (generations) transformations is derived from optima of positive synergies "coexistence and competition" of two generations, 
if $\xi=v_{i+1}: v_{i}=\sqrt{ } 2$, then roughly $\lambda_{i+1}=B_{i+1}: B_{i}=1,340$ and $\mu_{i+1}=A_{i+1}: A_{i}=\xi^{*} \lambda_{i+1}$, or $\mu_{i+1}=$ 1,896. The new generation (i+1) achieves higher speed in the reproductive cycle of productive transformations of $41.4 \%$, than the previous generation cycle (i). It follows that the effective potential $\mathrm{A}$ of new generation (i+1) is about $89.6 \%$ higher than potential $\mathrm{A}$, in the previous cycle (i) and at the same time spent potential B (resources) intergenerational rise about $34 \%$.

The result of the phenomena described above is:

a) physical extension of family business (the family of entrepreneurs) $t_{\mathrm{fi}+1}=(\varphi: \xi) * t_{\mathrm{fi}}$, thus approximately $\mathrm{t}_{\mathrm{fi}+1}=1,144 * \mathrm{t}_{\mathrm{fi}}$,

b) shortening of the business (working) time $t_{e i+1}=(1: \xi) * t_{e i}, t_{e i+1}=0,707 * t_{e i}$.

As a result of productivity growth of the family business is shortened productive (business) time between the following time cycles (generations) of around $29.3 \%$, but at the same time increase of the total potential of the productive system causes the physical renewal of time of existence of the following generation of approximately $14.4 \%$. There is therefore a paradox (the dilemma) of time: the new generation lives in business shorter time $t_{\text {ei+1 }}$, its business (innovation) life cycle is shorter compared to the original generation of (i), and at the same time, its physical existence time $\mathrm{t}_{\mathrm{fi}+1}$ is extended. Disparity or loss (excess) between the physical time and business between the following generations of the family business. Disparity (loss) in the following evolutionary cycles increases, provided that there are ideal conditions of spontaneous order of family business. Described phenomena bring into the family business a variety of other economic, social, ethical and other disparities. $[4,5,6,11,12]$.

\section{Discussion and simulation business}

Based on the above theory we can make the following estimates of the evolution of the potential business in the researched family companies.

The researched generation of entrepreneurs (i) will be in business (as owners) in diameter $t_{e i}=30$ years, as members of the business family will live approximately $t_{f i}=80$ years.

For the successors, based on the simulation of the evolution of family business, we could estimate that

a) the physical extension of family business (the family of entrepreneurs) of new generation ( $\mathrm{i}+1)$ will be approximately over 90 years of age, or $\mathrm{t}_{\mathrm{fi}+1}=1,144 * \mathrm{t}_{\mathrm{fi}}=1,144$ $* 80=91.5$ years,

b) and reaching the shortening of the business (working) time, which will exceed 20 years, so that $\mathrm{t}_{\mathrm{e} i+1}=0,707 * \mathrm{t}_{\mathrm{ei}}=0,707 * 30=21.2$ years.

Based on questioning in family companies it shows that the successor generation (i+1) begins to do business later (as owners) than their parents (between 30-35 years) and active business activity ends by transferring of the family business by their successors $(i+2)$ at about 55 years of their age.

This simulation describes the ideal state, ie the development of family business with maximum intensity and efficiency. The applied research of the authors of this article provides two key features:

a) family businesses in the Czech Republic are conservative and are more prone to savings and investments with less risk, so overall potential growth is usually slower than the ideal value $\varphi=1,618[11,12]$,

b) innovation dynamics in family firms in the Czech Republic usually do not reach the ideal value $\xi=v_{i+1}: v_{i}=\sqrt{ } 2$; only $3 \%$ of family companies included in the research sample were prepared for the Industrial Revolution $4.0[9,13]$, ie for higher-order qualitative innovations - according to the scale of F. Valenta 6th and higher order [17]. 
Summarizing the above research findings, we can define the real parameters of family business in the Czech Republic: ,
a) $\varphi^{\mathrm{r}} \in(1 ; 1,618)$
b) $\xi^{\mathrm{r}} \in(1 ; \sqrt{2})$.

Based on the processing of research data, we conclude that the mean value of the parameters of contemporary family business is $\varphi^{\mathrm{s}}=1,3 \mathrm{a} \xi^{\mathrm{s}}=1,2$. Then we can modify the previous simulation as follows:

1) The researched generation of entrepreneurs (i) will be in business (as owners) in diameter $t_{\mathrm{ei}}=30$ years, as members of the business family will live approximately $\mathrm{t}_{\mathrm{fi}}=80$ years.

2) For the successors, based on the simulation of the evolution of family business, we could estimate that

a) the physical extension of family business (the family of entrepreneurs) of new generation ( $\mathrm{i}+1$ ) will be approximately $\mathrm{t}_{\mathrm{fi}+1}=1,083 * \mathrm{t}_{\mathrm{fi}}=1,083 * 80=86.6$ years,

b) and reaching the shortening of the business (working) time, which will $\mathrm{t}^{\mathrm{s}}{ }_{\mathrm{ei}+1}=0,833 *$ $\mathrm{t}_{\mathrm{ei}}=0,833 * 30=25$ years.

The table shows the baseline data ( $\mathrm{tf} 0$ and te 0 ) and simulation data for the ideal variant $\left(t_{f_{i}+1}\right.$ and $\left.t_{e i+1}\right)$ and the intermediate variant $\left(t_{s f i+1}\right.$ and $\left.t_{s e i+1}\right)$.

Table 1. Simulation of family business dynamics in the Czech Republic

\begin{tabular}{|c|l|l|l|l|l|l|}
\hline Time & \multicolumn{1}{|l|}{$\mathbf{t}_{\mathbf{f 0}}$} & $\mathbf{t}_{\mathbf{e} \mathbf{0}}$ & $\mathbf{t}$ & $\mathbf{t}_{\mathbf{f i} \mathbf{+ 1}+\mathbf{1}}$ & $\mathbf{t}_{\mathbf{e i}+\mathbf{1}}$ & $\mathbf{t}_{\text {sei+1 }}$ \\
\hline Years & 80 & 30 & 91,5 & 86,6 & 21,2 & 25 \\
\hline
\end{tabular}

These simulations are presented in the following graph.

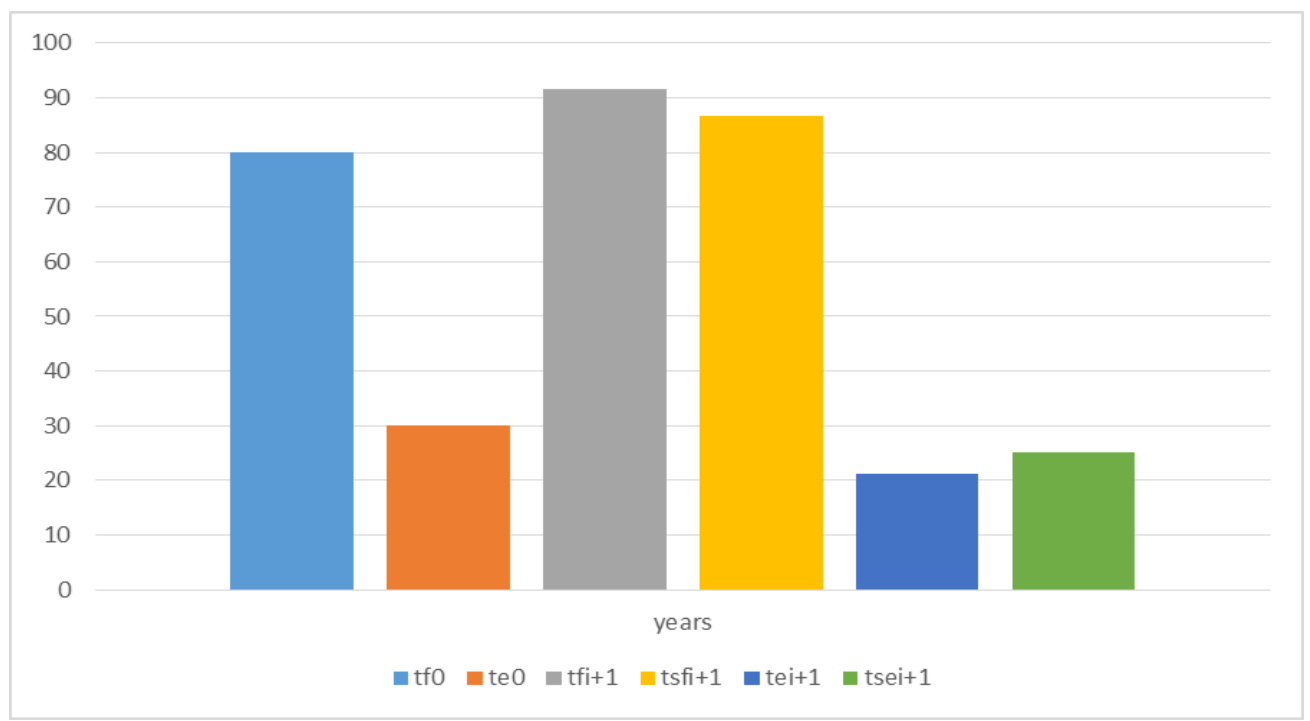

Graph 1 Simulation of family business dynamics in the Czech Republic 


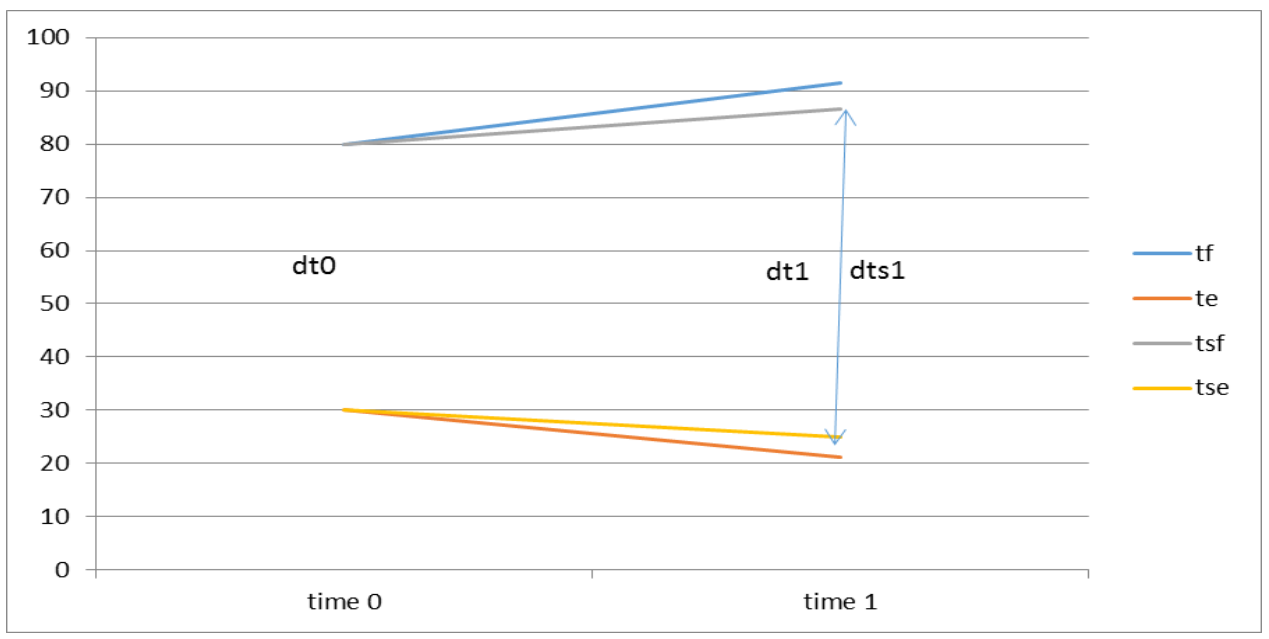

Graph 2 Disparity of time evolution

The disparity of time dynamics is shown in the graph and shows the variant fan between the optimal and medium trend:

a) default disparity is $d_{t 0}=\left(t_{f 0}-t_{e 0}\right): t_{f 0}=(80-30): 80=50: 80=0,625$

b) optimal disparity trend is $d_{t l}=\left(t_{f 1}-t_{e l}\right): t_{f 1}=(91,5-21,2): 91,5=70,3: 91,5=0,768$

c) the mean disparity trend is $d_{t s l}=\left(t_{s f l}-t_{s e l}\right): t_{s f l}=(86,6-25): 86,6=61,6: 86,6=0,711$.

The conclusion is obvious from these results. The disparity of time is increasing under the influence of natural, technical, economic, social and psychological factors. The scissors between $t_{f}$ and $t_{e}$ open and pose considerable challenges. Pressure can be expected on qualitative changes in family development, entrepreneurship and in the priorities of society and the environment.

This means that there will be changes in the concept and functioning of families, changes in the governance of family businesses etc. under the influence of the industrial revolution ( 0.4 and following). We must also be aware of the historical context of family business research in the Czech Republic and the "new" EU members:

a) In post-socialist countries, especially in the Czech Republic, the family was renewed after about 50 years around 1990. The period of World War II completely suppressed the business of Jewish families and significantly reduced the business of the Czech population if it did not collaborate with fascists. The revival of family business after World War II was fully suppressed after 1948. As a result, before privatization (before 1990), the private sector in the Czech Republic had only $1.2 \%$ of property value and $2 \%$ of labor force in employment. From the above calculations and simulations follows the contemporary paradox. Entrepreneurship (incl. Family) has been developing in the Czech Republic again after 1990, therefore there are not enough families with a complete reproductive cycle of the next three generations, which is necessary for revealing the nature ("DNA") of family entrepreneurship in specific cultural, social, economic etc. state (eg Czech Republic). In this situation, the validity of the above model cannot be statistically verified at present. It is therefore a theoretical model derived from empirical knowledge and formulated on research principles other than statistical data analysis.

b) The advent of the Industrial Revolution 4.0, new technologies, socio-economic, cultural and other factors of the contemporary concept of entrepreneurship and social life raises the need to create new theoretical models of family business. 
From this it can be inferred that these results come from the preservation of conservative values in families and national cultures of inter-generational conflicts, from the selective impact of globalization on social classes and business entities, etc. All referred findings it is possible to compare with the findings of other authors listed in the list of sources for this article.

It follows from the above text, the family business model and the available sources that there is a time when it will be necessary to reformulate the definition of basic paradigms, such as family definition, entrepreneurship, social evolution, etc.

\section{Summary of findings}

The evolutionary theory of the family business and related practical experiment introduces several final findings.Family firms represent the typical features of the business subject to objective and subjective spontaneous order. In the ideal (harmonic) variant very few companies work (these companies have already existed for a series of successive generations, even centuries). According to experts, a very risky is the third business generation $(i+2)$, which only represents a few percent (2-3\%) of companies founded by the first generation (i). This fact is not possible to verify in the Czech Republic, because at present, the transmission of the family companies from the first (i) on the second (i+1) generation is in progress.

It is confirmed the formation of evolutionary networks of family business (both in terms of the dynamics of the potentials, and in terms of the economics of time). By means of the comparative analysis we came to the conclusion that it can be applied successfully in research of spontaneous order within the theory of innovation by Professor František Valenta [17].

The group of family companies, which move beyond the ideal variant of development of spontaneous order, we can mean of rationalisation innovation. F. Valenta distinguishes four systems of rationalisation innovations, whereas the basic rule for the recognition of rationalisation innovations with different order is a finding what can sustain on existing economic status process (technical, social, economic, etc.), and what is going to be changed by innovation. This idea raises additional research orientation of the family business.

While every qualitative change remains something of the original initial element and something qualitatively changes. Then we are looking at the qualitative change from the perspective of what has changed, and this is something new, or we are looking at in terms of what persists, then it is an enhancement of what persists in a new quality [14].

Advanced the ideas of F. Valenta [17]., we see that innovation of the 6. order is innovation at the level of the new generation, which represents the start of production (transformation, manufacture or application) of the new economic subject (product, the production factor, technology, in our case the family company), which is from the closest relatives' other subjects diversified with a completely new structural (design or otherwise defined) layout (i.e. a solution to all its property, work, control functions, etc.) relevant to the user (owner).

If we convert this concept on family business, then we would understand for the fundamental qualitative innovation (6. order) in the family business the intergenerational succession of the family business by its successors. Therefore, it is a family business innovation on the level of the new generation of successors that represents business in undertaken or started a new business derived from the closest business relatives (genetically or adoptive), established with significantly different (new) concept, style, new business issues (or potential) and solution of business functions, relevant for the family, a business entity (company) and the relevant business environment. 
We may declare our opinion, that the social and "industrial revolution" 5.0 is getting near and other global economic, social, cultural, ecological and other contemporary turbulences, built on the "microcosm optimization" of living matter, having two extreme marginal variants for the next (evolutionary) development of family business [13].

The present research has come to the fragmentary conclusion. The key factor for business development at the present time is the innovation process in the area of technology, often completely new and hitherto virtually unknown. Family businesses to absorb this trend, they should proceed to internal changes in paradigms and the dogmas of the behaviour of the families. There should be the innovation in behaviour of the families. It is essential that the successors should be trained from childhood to entrepreneurship, to contemporary technological mind-set, to maintain family traditions and values in the new historical and social context. Our conclusions are also confirmed by the latest medical knowledge, especially psychology, psychiatry and genetics.

The submitted theory deserves a broad discussion and further verification in practice, depending on the cultural differences in manifestations of globalization in various parts of the world and under the influence of the industrial revolution 4.0 or 5.0 ingoing, the migration of nations, environmental changes, etc. We should be aware of the current world is turned, without we exactly know what it will follow. Therefore, each expert opinion and scientific discussion are completely necessary and useful.

Roughly 30 years of renewed entrepreneurship and especially family entrepreneurship in post-socialist countries provide a number of incentives for theoretical research that do not have a knowledge base in a world where entrepreneurship has not been discontinued due to a different social order than in post-socialist European countries

\section{References}

1. B. de GROOT, H.P. Frances. Cycles in basic innovations. Technological Forecasting \& Social Change, vol.76. (2009)

2. D. Filson, Product and process innovations in the life cycle of an industry. "Journal of Economic Behavior \& Organization", Vol. 49. (2002).

3. M.Horooka. Nonlinear dynamism of innovation and business cycles. Journal of evolutionary economics, vol. 13, no. 2003. (2003).

4. A.Ključnikov, M. Civelek, P-Čech, J.Kloudová, Entrepreneurial orientation of SMEs' executives in the comparative perspective for Czechia and Turkey. Oeconomia Copernicana, 10(4), 773-795. doi: 10.24136/oc.2019.035, (2019).

5. A. Ključnikov, A. Uncover SMEs finance through the impact of the specific factors. Evidence from Slovakia. Transformations in Business \& Economics, Vol. 15, 2B, pp.741-754, ISSN 1648 - 4460. (2016).

6. A. Ključnikov, A., J. Belás, J., L. Smrčka, L. (. The Role Of Risk-Taking And Competitive Aggressiveness In Management of SMEs. Polish Journal of Management Studies, 14 (1). ISSN 2081-7452, DOI: 10.17512/pjms.2016.14.1.12 (2016)

7. Z. Mikoláš, V.Fialová,. The Dilemmas of the Power of Market Economy. Studia Ekonomiczne. Zeszyty Naukowe, Nr 303, s. 9 - 23. Uniwersytet Ekonomiczny w Katowicach, (2016).

8. Z. Mikoláš, J. Peterková, Dilemas of Innovative Dynamism and Social Responsility. In. Interantional Journal of Investment Management and Finacial Innovations. Volume 2, Issus 1/2015, p. 35-40, (2015).

9. Z. Mikoláš, Z.Wozniaková, Synergic Time Effect of Intelligent Enterprise. In. Interantional Journal of Latest Research in Science And Technology. Volume 3, Issus 3, June 2014, (2014). 
10. Z. Mikoláš, Potential Theory and Innovation Dynamics of Enterprise. Studia Ekonomiczne 2014, nr 183, s. 197 - 204, Uniwersytet Ekonomiczny w Katowicach, Katowice, (2014).

11. Z. Mikoláš, Potenciál rodinného podnikání. S. Majtán (red.), Aktualne problemy podnikovej sfery 2016: zborník vedeckých prác, Bratislava, Vydavatelstvo EKONÓM, s. 750-757, (2016).

12. Z. Mikoláš,J. Karpeta, Family business - the Potential for futher Business Development in the Czech Rupublic. International Journal of development Research. Volume 5, Issue 06, June 2015, (2015).

13. Z. Mikoláš, Z.Wozniaková, Soudobá paradigmata rodinného podnikání v České republice na počátku průmyslové revoluce 4.0. In. Štefan Majtán (ed.) a kolektív; Atuálne problémy podnikovej sféry 2017. Zborník vedeckých prác. Bratislava: EKONÓM, s. 735 - 744, (2017).

14. J. Peterková, Využití konceptů inovací v průmyslovém podniku. VŠB-TU Ostrava: Series on Advanced Economic Issues, Faculty of Economics, (2017).

15. S.D.Sarasvathy, Effectuation. Elements of Entrepreneurial Expertise. Cheltenham: Edward Elgar, (2008).

16. O.Scott, Záhadný zlatý řez. Praha: Dokořán, (2013).

17. F.Valenta, Tvưrči aktivita, inovace, efekty, Praha:Svoboda (1969) 